\title{
A Closer Look at Junior High School English Teachers in Pekanbaru: Does the Reluctance of Teachers to Adapt with ICT Hindering English Learning?
}

\author{
Wendy Simangunsong \\ Universitas Lancang Kuning, Pekanbaru, Indonesia \\ wendysmani1@gmail.com
}

\begin{abstract}
ARTICLE HISTORY
Received : 23 August 2019

Revised : 25 August 2019

Accepted : 27 Septemebr 2019
\end{abstract}

\section{KEYWORDS}

Information and Communication Technology (ICT)

English Learning

Junior High School Teachers

Teaching Process

\begin{abstract}
Though English Education has universally acknowledged technology as a fundamental consideration, there exists a gap between the IT skills of teachers and students due to teachers' reluctance to adapt Internet/information communications technology (ICT) in their English teaching. This paper looked closely at 131 junior high schools in Pekanbaru, Indonesia to ascertain if the conservative teaching mindset may be preventing English learning of students. Mixed method is used to analyse the data collected from 171 English teachers through online and offline questionnaires from a previous study that uncovered 5 key problems of ICT usage in teaching English, namely teachers' lack of IT knowledge, lack of ICT facilities, lack of self-confidence, lack of much time, and lack of willingness to change their teaching style. The key finding of this survey is that while technical problems are numerous, the biggest obstacle for the improvement of junior high school English teachers is their reluctance to learn new ICT tools and adapt with their students' modern technologies.
\end{abstract}

\section{Introduction}

Schools first took the form of one-room cabins, pursuing the life-long mission to make citizens moral and literate. Educational tools were few, and comes in the form of wooden paddles with printed lessons. Back then, chalkboards and books were viewed as radical teaching tools as they come around in 1890s (Haran, 2015). Pencils in 1990, radios in 1920s, overhead projectors in 1930 , videotapes in 1951, photocopier in 1959, calculator in 1972. Developed in the 1930s, computers became an 'everydayitem' in 1980s, and Seymoour Papert became the first person recorded on history to realize that computers could be used to support education (Livingston, 2016). MySpace in 2003, Facebook in 2004, Twitter in 2007, Instagram in 2010, and numerous other social media got engineered by educated experts and high school kids came to be. Nowadays, virtual reality and $3 \mathrm{D}$ printing are the radical educational technologies. Education becomes compulsory in 1763, pioneered by Prussia (Melton, 2003), and currently countries leading in the implementation of Internet/information and communications technology (ICT) in education are Abu Dhabi, Kuwait, and Taiwan. Virtually every K-12 and higher education around the world has adopted technologies in their teaching process (Nagel, 2014), the latter especially because "technology is most effective when students use the Internet in the classroom for guided research and project work" (Chowdhry, 2015). The case is the same for Indonesia. Conventional wisdom finds this reasonable considering the sheer number of advantages and opportunities information and communications technologies (ICT) has to offer to the field of education.
In the same respect with technology, English language also gives limitless opportunities for learners. As recent as June 23rd, 2019, United States Census Bureau estimated that the population of the world is currently 7,711,619,227 people (and the live count changes every second), and at least 2 billion are English speakers (US Census Bureau, 2019). Understanding basic English at the very least lets one to communicate with almost "a quarter of the amount of people on the planet," which is possible because of social media. While nearly anyone is able to upload their content on the Internet, to reach the wider audience people who upload content generally use English. Therefore, English speakers could understand more than $50 \%$ of the everconstantly updating content in the Internet. Materials and guides of various genres and subjects means that English learners have endless resources for entertainment and selflearning. As videos become more consumable and easier to make, English learners could obtain visual demonstrations of various types of skills and techniques to hone their hobbies or advance their careers. Self-reflection would also gain more depth whether by intellectual debates, fictional stories, studying and traveling abroad (Derin \& Hamuddin, 2019). In essence, understanding English makes it easier to understand the world.

As opposed to this optimistic view on ICT's impact on children's education, Organization for Economic Cooperation and Development (OECD) reported a few years ago that the impact of ICT is mixed at best (Chowdhry, 2015). The report showed data from 31 countries which schools heavily invested in ICT for education, yet there is little improvement in student achievement. The most 
significant factor the report put forward is proper implementation and regulation, as without it, technology will only become a distraction. However, this 2015 research report's results didn't consider different cultural contexts in regards to ICT in classroom, so the impact of ICT being "mixed at best" may be better in specific locations. This paper is focused on the education culture of Indonesia, specifically on the city of Pekanbaru. One thing that should be underlined from this report is that moderation of ICT usage seems to be the key to achieve maximum outcome of ICT in classroom.

Ultimately, because both technology and English are now universal and endemic part of almost everyone's daily lives, schools as a place where children learn must be able to make students savvy with technology and the universal language (Coughlan, 2015). Schools worldwide have acknowledged that they must no longer be monotonous training simulation for industrial work, but reach the larger picture that is sustainable developmental goals by producing competent and moral life-long learners.

In the context of English teaching and learning, teachers make use of social media to make students interact using English as much as possible. It could be though private chat or group forum. Students film their performances in front of the class and upload them on YouTube, or write about their lesson material on their personal blogs (Hamuddin, 2016). Some schools switch writing essays on paper for writing them on the computer for students to upload in their class blogs for easier viewing and plagiarism-checking. Interactive multimedia is a popular choice to increase English listening, reading, speaking, and writing skills (Andriani, 2016; Andriani, 2018; Andriani \& Dewi, 2018; Andriani \& Kasriyati, 2018; Dahler \& Yani, 2017), and supports the shift toward blended, online, and technologydriven collaborative learning.

As any process of modern progressiveness, technological challenges remain to be an obstacle. Three of the most famed problem include lack of information technology (IT) skills, lack of confidence in using ICT, and cyberbullying (Hamuddin et al., 2018). One of the latest reports for policymakers sums up the most critical tech issues for education today (Educational Technology Cooperative, 2018). Data system is still widely uncharted territory for many schools because of the lack of common definitions of data across K-20 education. Insufficient digital literacy level leads to predictive analytics being inadequate in decision-making and modeling for better student outcomes, two issues exacerbated by unreliable and costly bandwidth which further worsens when it has to accommodate for more than twenty students accessing the Internet at the same time. Wide adaptation of new learning models is going slowly, especially for schools that are content with school-wide grading policy than personalized, competency-based policy, let alone one that factors the relevance of emerging technologies to reach maximum benefits for students and educators. Many students themselves are still unaware or unable to make the best use of e-learning. There is also a gap between internet enabling users to educational information and internet risking users' privacy, an issue further risked by scant technology security that is supposed to protect the system from unauthorized access. Therefore, maintaining regular review of the technology-related policies on education becomes a hard task.

Problems of the technologies are not the only obstacles English teaching and learning faces. In the past few years, scholars found that there are systemic challenges, that is problems that comes from the educators' side (Nagel, 2014). Systemic challenges largely take form as the reluctance of teachers in using ICT in their teaching process. A previous experimental study of junior high school teachers in Pekanbaru concluded that in Pekanbaru, there are at least five most common issues in the implementation of ICT, namely the schools' lack of ICT facilities, and the teachers' lack of IT knowledge, selfconfidence, time, and willingness to change their teaching style. This paper sees that, based on the study, the biggest overall challenge is the educators' reluctance to adapt.

This paper discusses the issues of using ICT in English learning and teaching in Pekanbaru, with a focus on the systemic type of challenges that stems from the educators' side rather than the technology or the students' side, though those will still be included by virtue of how intertwined they are in education. With majority of teachers' preference for 20th century teaching practices, the broad goal of this paper is to ascertain if adding 21 st century technologies will dilute the effectiveness of teaching. Meanwhile, the specific goal is to answer the question if junior high school teachers' reluctance to adapt to this addition causes English learning in Pekanbaru schools to be less effective than expected

\section{Method}

This paper used mixed method, consisting of qualitative and quantitative research methods. For qualitative, this study employed library research process, which involves extensive information gathering that necessitates continuous narrowing of a broad topic. The authors chose this method because classroom technology has become a broad field, whereas to focus on a limited area and educational level of this paper the authors need to identify and locate relevant information that may not be readily available as primary sources.

The qualitative method complements the quantitative data which uses primary data from the result of a previous quantitative study that collected data from 171 respondents out of 180 junior high school English teachers in Pekanbaru city of Indonesia. The demography of the respondents contributing to the primary data of this paper is shown in the chart below, detailing the teachers' amount of experience and frequency in using ICT. 


\section{Results}

The researcher collected the data from 171 respondents and quantified the percentages. The length of time junior high school teachers in Pekanbaru uses ICT can be seen in Chart 1 , whereas the frequency of their usage can be seen in Chart 2.

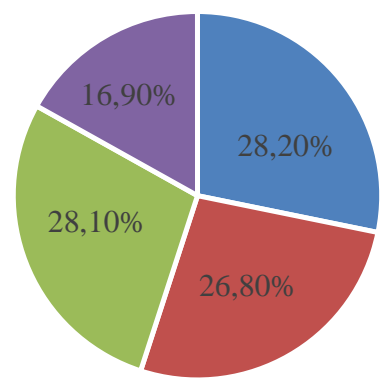

$$
\begin{aligned}
& \text { - Less than } 6 \text { months }-6 \text { months }-1 \text { year } \\
& -1 \text { year }-2 \text { years } \quad \text { More than } 2 \text { years }
\end{aligned}
$$

Chart 1. The length of time teachers use ICT

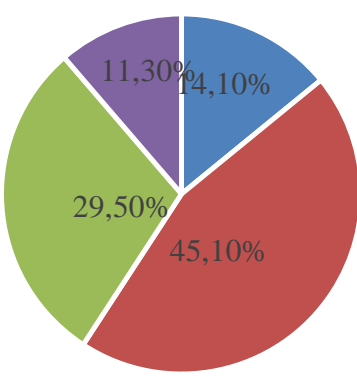

- Never - Rarely - Often - Very often

Chart 2. Frequency of use of ICT facilities

According to both charts, more than half $(55 \%)$ of the teachers are still relatively new in using ICT in their teaching process, and only $16.9 \%$ have more than 2 years of experience in using ICT. However, by far $45.1 \%$ of all respondents rarely use technology in their classroom, and $14.1 \%$ admitted that they never used ICT.

Therefore, to further evaluate the findings from the previous study's results, this paper uses numerous library sources in exploring the findings more in-depth. This qualitative method combed through $\mathrm{XX}$ sources from
Pekanbaru and $\mathrm{XX}$ sources from various repositories to deepen insight in the discourse of ICT for education.

\subsection{ICT Progress in Pekanbaru}

Observing the latest trends, ICT usage in education is now dealing with eye-tracking technology called biometrics for online teachers to tell if online students are truly paying attention to the screen, and augmented reality (AR) glasses and virtual reality (VR) to allow real-world learning experience through educational games and simulations. Pekanbaru has a high need of information technology, mostly because of its high activity in commerce and service (Syahputera, Hidayat, \& Rijal, 2015), though ICT usage in education is not that advanced yet. To simplify the status quo, ICT creates demands on education, but education is not fast enough to follow after its rapid development (Hamuddin et al., 2019).

Firstly, supplying computers to junior high schools and allowing phones to be used to quickly gather many information do increase students' computer proficiency, but not necessarily their academic outcomes. If the lesson plan includes using computer to learn the lesson materials, it is often the case that the homework assignments would be web-based. But not all students have access to computers in their homes. This situation not only exacerbates the existing educational inequality by making studying harder for students from poorer families, it drives children to go to Internet cafes, colloquially known as warung internet (warnet), which is mostly used by addicted game players and teenagers who often skip classes.

Secondly, games that are educational are highly promoted, but the number of students who would voluntarily play games that engages them in logic, mathematics, or science is not significant. Not to mention, schools in Pekanbaru often could only afford poor educational software. Many times, technology companies would sell the educational tech as if they are faster textbooks or fancier boards, serving the market more than the students.

For a few schools, their investment in technology becomes a point of contention as the school prioritizes investment in tech than in teachers. Thankfully, Pekanbaru's campaign is nowhere near as overblown as Kenya's digital literacy campaign that spent USD \$173.5 million on tablets (Livingston, 2016). For the moment, technological campaigns should encourage learning ICT, with a reminder to be judicious (Butrymowicz, 2014). Investment in technology also invites risks that comes with the usage of ICT, so technical risk assessment must also be a point of concern for schools to assess the level of risk and preparation of using their technology (Megawati \& Putra, 2017).

Lastly, smart technology doesn't necessarily mean smart students. In fact, technology out-thinks both the students and teachers. With calculators and applications that could 
solve problems that students are supposed to struggle with, sometimes students choose the easier solution (Heick, 2016). Even teachers aren't immune to choosing this "easier solution", diverting students' questions by telling them to search answers since 'they have Google' to, if not challenge the students, avoid admitting they do not know the answer to the question.

But the situation is not permanently bleak. The setbacks education has undergone in the process of adapting with technology has revealed better ways to approach it. ICT seems to be most effective when it is used to develop everyday life adult skills, namely "finding resources, critiquing arguments, communicating with peers, solving problems and working with data" (Chowdhry, 2015). Curriculums that are aligned with these skills benefit the most with ICT usage (Andriani \& Kasriyati, 2018; Hamuddin, 2016), and it seems ICT is not as effective when it is simply stuck on the old paradigm of lecturing and homework. At the moment, junior high school English teachers are evenly divided in their preference of using ICT facilities $(56.3 \%$ like, $43.7 \%$ dislike) and comfort of sticking with conservative teaching mindset $(50.7 \%$ prefer using modern method, while $49.3 \%$ prefer using conventional method).

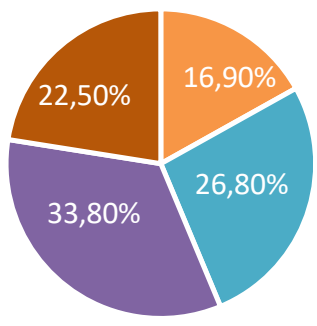

$$
\begin{array}{ll}
\text { - Strongly agree } & \text { - Agree } \\
\text { - Weakly disagree } \quad \text { - Strongly disagree }
\end{array}
$$

Chart 3. Teacher's preference of using ICT

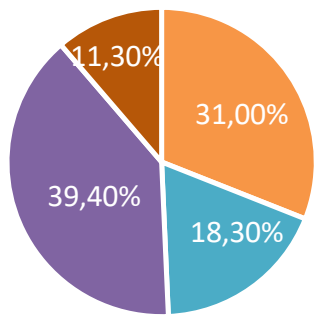

$$
\begin{array}{ll}
\text { - Strongly agree } & \text { - Agree } \\
\text { - Weakly disagree } & \text { - Strongly disagree }
\end{array}
$$

Chart 4. Teachers' comfort in using ICT
With these in mind, this paper sees that technology that is able to improve education can be double-edged in two ways. First, the need of technology could potentially cripple schools if they are careless in how they procure it. Second, once obtained, teachers and students must understand that ICT is their learning tools, not a crutch to fulfill the targets of specific lesson plans. They must also realize that ICT should be used in moderation, not as a permanent tool when learning lest the education outcome will be weaker, as seen in OECD 2015 report. If teachers are not adjusting their pedagogies with modern needs and current era's daily-used conveniences, not only would school investments in ICT become a waste, the teaching effectivity becomes diluted (Shapiro, 2015; Herlinawati, 2011) because rather than the 'learning aid' it is, ICT is viewed as 'confusing distractions.'

\subsection{Junior High School Teachers in Pekanbaru}

ICT introduces advantages and endless possibilities for the development of teaching and learning process. Indonesia's Ministry of Education and Culture rigorously hold routine workshops increase educators' motivations to teach using technology. A junior high school English teacher attending one of the workshops said that using laptop and projector significantly eases the learning process, and admitted that to do so teachers must make time to upload the images or videos needed for the lessons (Maulipaksi, 2016). This is actually one of the most common practices of using computers in junior high school classes in Pekanbaru. It is when either the teacher or a group of students take on the role of educator and use a slideshow and deliver the material. While in theory it mimics successful first-class seminars, in practice the students are hardly experienced or invested speakers. Many of the junior high school students do not act as audience, but simply mind their business in their phones if phones are allowed in class, or with their friends near their seats.

When phones are allowed or encouraged to be used in class, the most common practice seems to be when the teacher asks a question, and when none of the students could answer (or simply too shy to speak up), the teacher tells them to search for the answer on their phones, lets time pass by while he/she continues to prompt the students whether or not they have found the answer. It has been observed that in some junior high schools, the students sometimes keep their silence, forcing the teacher to eventually pick one among them to try to give their best answer.

In both practices above, some teachers could even sit on their desks to use their phone or laptop, quietly letting time pass by unacknowledged as students perform or search for answers. This bred the phenomena in which students could go through class playing non-educative games on their phones instead of learning. "The role of the educator is being challenged as resources become more accessible on 
the Internet" (Lien, 2017), yet not all of the resources available are beneficial ones or is the one being accessed. Unfortunately, schools haven't become good enough for their pedagogies to maximize the usage of ICT, leading to the advent of naïve policy strategies (Shapiro, 2015), such as the ones described above.

One possible solution that might be effective to the problem of technology's nature as distraction for children and even for the teacher is to be strict with time. After introducing the day's lesson material briefly, the teacher could have the students race against he/she's digital stopwatch and the moment it's over, the teacher will lead the discussion. If all the students are involved, voluntarily or by prior prompting, computers and phones would be out of mind. However, time management is actually a huge issue in Pekanbaru, to the point that it is so common ill or lack of time management is often not considered a 'problem' for the locals. Some junior high school students who are of the opinion that their teacher or school cannot punish them misbehave by joking and egging the class to laugh and be loud, and this is quite hard for teachers to control to make the class conducive for learning again. According to the data collected from 171 English teachers from 131 junior high schools in Pekanbaru, chart 3 below shows $56.4 \%$ believe they barely have time to utilize ICT in their classroom. This is reflected by chart 2 above that revealed $55.2 \%$ rarely, if ever, use ICT as alternative media.

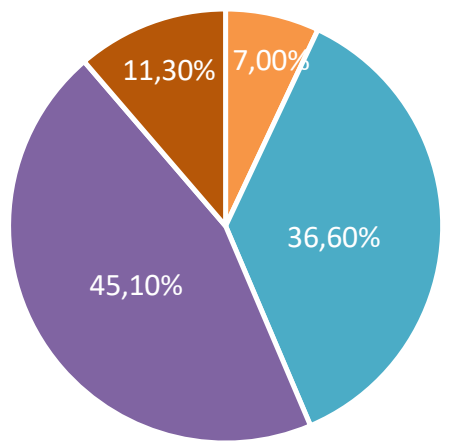

A lot of time Enough time Little time No time

Chart 3. Effectivity of time used to utilize ICT facilities

Many teachers share these problems and numerous discussions around this nature has cropped up. It seems that a significant cause behind teachers' reluctance stems from the lack of support of their professional development. "All too often, when schools mandate the use of a specific technology, teachers are left without the tools (and often skills)" (New Media Consortium, 2013). Due to the low investment in teachers' progress outside of the school's facility improvement, teachers themselves become prone to resist the adoption of ICT in their teaching process. Too often when new technology emerges, inexperienced teachers simply stop after exclaiming 'wow,' than ponder how it may be useful for their teaching and self-learning. Because they are unequipped to deal with the change, they find the status quo of using traditional teaching methods more comfortable and preferable, and consider technology in class 'troublesome distractions.'

\subsection{English Learning Using ICT in Pekanbaru}

The fact is, English has "forced almost all parts of the world to use English as the main communication language," so teachers of nearly every subject now has a small obligation to at least address the relevance of being competent if not highly proficient in English to the students. In Pekanbaru, a hotbed town of students coming from many different rural areas with their specific local languages as their preferred daily language choice, even over the national language of Indonesia, English learning in Pekanbaru is quite the struggle. While many students feel a high need to be proficient in English, many of them do not learn the language outside of class (Gowasa \& Derin, 2019). Even during class many students achieve mostly the minimum requirement to pass the class rather than to truly learn the foreign language. It is hoped that since these students are using technological devices short of 24/7, Pekanbaru can leverage ICT to induce self-learning and personal autonomy for students (Hughes \& Berry, 2011).

However, considering the findings of a previous study which collected data from junior high school English teachers who are dominantly reluctant to leverage ICT, this paper suggests teachers to also do self-learning and personal autonomy. It seems unreasonable to expect or even command students to be responsible in their English learning for modern world purposes when teachers, who are supposed to be the students' role models, are unwilling to do address their lack of IT knowledge, self-confidence, and willingness to change their teaching style and lesson plans to accommodate ICT.

One of the most successful ways students leverage ICT in their English learning is liberally using social media such as WhatsApp or LINE to create online classes and seminars (Parhusip \& Haloho, 2018). Better established digital bootcamps for learning exists, such as ruangbelajar or Skillshare, but students excellently use the technology they already have (i.e. laptop, phone apps) to establish groups consisted of their peers from their schools, cities, and all over Indonesia, with the specific goal of learning. It has a few downsides, such as lacking face-to-face experience of learning English, and oftentimes the members in the group would mainly use Indonesian instead of English though their study groups were made for the purpose of learning English. However, when their English teachers come into the group, the students would communicate using English. This study notes an interesting parallel that when teachers are actively using English in class the students have high reluctance in reciprocating, but not so much on social media. While it may mean that this is because there is a 
different level of courage needed between speaking and texting, teaching through social media at least urges the students to use English more. This may be of interest for further study.

\section{Conclusion}

Technological issues come in many forms (the most common ten of them includes digital literacy, data system, data privacy, predictive analytics, bandwidth, new learning models, emerging technologies, technological security, digital accessibility, policy), but they are not as much of an obstacle as a teacher's reluctance to learn for themselves to effectively use the technologies in teaching.

To recapitulate, teachers need to be more open-minded and willing to get out of their comfort zones. The possibilities for students' future can be limitless if schools successfully leverage real-time access to up-to-date knowledge and the best teachers anywhere. This paper cautions any parties interested in ICT to keep in mind that while technology may amplify teaching to be great, it cannot replace poor teaching. Most importantly, what will truly drive teachers to become great educators is the less visible conditions, that is the support of the principal/department head and colleague in a collaborative, idea-exchanging environment.

\section{Suggestion}

Observing how the leading countries implement ICT in their education, this paper gives a few suggestions. First, schools in Pekanbaru should hire IT specialist to identify emerging software and hardware that can be used in the classroom. Second, while allocating iPads for each student is currently impossible, using social media to give additional lessons such as quizzes is entirely plausible. Third, it is not too late for teachers to try making videos of their lessons, during class session or outside of it. Not only would it increase teachers' visibility on media and become a contribution to online education, their students could view the class again for their exam preparation reviews, and teachers could reflect back on their teaching methods. If making videos is too time-consuming or challenging, simple text message reminders of tips, goals, and encouragement can have meaningful impact on the students.

Something to consider is the adaptation of education assessment. Despite the numerous challenges that are still present for more than a few years, students, teachers, and the school facilities are adapting to modern need of ICT. The case is not the same when it comes to the school assessment. There is still a gap in how the curricula has include technology in English teaching and learning but the assessment of the teaching and learning process remains relatively the same. Current assessment is largely seeing if the facilities are adequate enough, if the teacher is competent enough, and if the students are good enough to grasp the core lessons. These are mainly ticked off as 'good' if the assessor considers the classroom to be a comfortable learning environment, sees the teacher able to control the students from misbehaving, and concludes that the students are capable to the questions given to them. This generic assessment most likely fails teachers' using ICT in their teaching process because when a classroom adopts using ICT such as laptops or phones, the students would look down than look up at their teacher, sprawl about than sit straight in their proper seats, and ask their friends around to make sure they're on the same track than fully engaging with the teacher

\section{References}

Andriani, R. (2016). Improving Students' Vocabulary Mastery using Interactive Multimedia. ELT-Lectura, 3(1).

Andriani, R. (2018). The Factors influence the Students' Learning Outcome in Translation Subject by Using Android. ELT-Lectura, 5(2), 183-188.

Andriani, R., \& Devi, W. (2018). Improving Students' Writing Skill in Narrative Text by Using Storybird. ELT-Lectura, 5(1), 78-85.

Andriani, R., \& Kasriyati, D. (2018). Pembuatan Media Pembelajaran Berbasis Multimedia bagi Guru Sekolah Dasar (SD) Kecamatan Rumbai Kota Pekanbaru Provinsi Riau. J-ABDIPAMAS (Jurnal Pengabdian Kepada Masyarakat), 2(2), 119-126.

Butrymowicz, S. (2014). How does one of the topperforming countries in the world think about technology? The Hechinger Report.

Chowdhry, A. (2015). Computers in classroom have 'mixed' impact on learning: OECD report. The Globe and Mail.

Coughlan, S. (2015). Computers 'do not improve' pupil results, says OECD. BBC News. (15 September).

Dahler, D., \& Yani, N. A. T. (2017). The Effect of Using New American Lecture Strategy on Students' Reading Comprehension. Indonesian Journal of Integrated English Language Teaching, 2(2).

Derin, T., \& Hamuddin, B. (2019). Foreign Language Classroom Anxiety, and Enjoyment During Study Abroad: A Review of Selected Paper. Lisan: Jurnal Bahasa dan Linguistik, 8(2), 76-82.

Educational Technology Cooperative. (2018). 10 Critical Issues in Educational Technology: To improve education, address critical technology issues now. Southern Regional Educational Board (SREB).

Gowasa, N. S., \& Derin, T. (2019). Observation Report on the English Classroom Management of SMA Olahrage Rumbai-Pekanbaru. 
Hamuddin, B. (2016). Using blog to Promote English Skills for EFL Students: The Students' Perception. ELTLectura, 3(2).

Hamuddin, B., Julita, K., Rahman, F., Syaifullah, \& Derin, T. (2019). Artificial Intelligence in EFL Classroom Environment: Lyra Virtual Assistance for Speaking Skill Improvement.

Hamuddin, B., Kurniawan, K., Syaifullah, S., \& Herdi, H. (2018). Detecting Major Problems in Learning English Through Blog-based Class. Journal of Education and Learning, 12(3), 529-537.

Haran, M. (2015). A History of Education Technology. Institute of Progressive Education \& Learning.

Heick, T. (2016). 5 Problems with Technology in Classrooms. Teach Thought.

Herlinawati. (2011). The Effectiveness of Indonesian English Teachers Training Programs in Improving Confidence and Motivation. Online Submission, 4(1), 79-104.Livingston, S. (2016). Classroom Technologies Narrow Education Gap in Developing Countries. Brookings.

Hughes, B. J., \& Berry D. C. (2011). Self-Directed Learning and the Millennial Athletic Training Student. Athletic Training Education Journal. 6(1). 46-50.

Maulipaksi, D. (2016). Gunakan Teknologi untuk Mendukung Proses Pembelajaran. Ministry of Education and Culture of Indonesia. (1 August).

Megawati, M., \& Putra, K. E. (2017, May). Pengukuran Resiko Jaringan Komputer Menggunakan Technical Risk Assessment pada SMK Muhammadiyah 2 Pekanbaru. In Seminar Nasional Teknologi Informasi Komunikasi dan Industri (pp. 293-298).

Melton, J. V. H. (2003). Absolutism and the eighteenthcentury origins of compulsory schooling in Prussia and Austria. Cambridge University Press.

Nagel, D. (2014). 6 Technology Challenges Facing Education. Wabisabi Learning.

Nasution, F. B. B., \& Bazin, N. E. N. (2014). Adjusting ICT Capacity Planning by Minimizing Cyber Crime Effects in Urban Area: A System Dynamics Approach. Proceeding of the Electrical Engineering Computer Science and Informatics, 1(1), 40-45.

New Media Consortium. (2013). The NMC Horizon Report: 2013 K-12 Edition. New Media Consortium.

Parhusip, K., \& Haloho, H. (2018). Pola Komunikasi Tutor dan Siswa Melalui Whatsapp Dalam Program Ruangguru Digitalbootcamp Paket C. Widya Komunika, 8(2), 1-17.
Shapiro, J. (2015). Technology in Classrooms Around the World? Still Buggy and Here's Why. Forbes.

Syahputera, A. S., Hidayat, W., \& Rijal, M. (2015). Information Technology Center Di Pekanbaru Dengan Pendekatan Arsitektur High Tech. Jurnal Online Mahasiswa (JOM) Bidang Teknik dan Sains, 1(2), 1-15. 